\title{
Physico-chemical investigation of honey samples from bee farmers in Ekiti State, Southwest Nigeria
}

\author{
Joshua Kayode, Sunday Dele Oyeyemi* \\ Department of Plant Science, Ekiti State University, Ado-Ekiti, Nigeria \\ Emails address: \\ jokayode@ymail.com (J. Kayode), delejohnson6817@yahoo.com (S. D. Oyeyemi), sundaydeleoyeyemi@gmail.com (S. D. Oyeyemi) \\ To cite this article: \\ Joshua Kayode, Sunday Dele Oyeyemi. Physico-Chemical Investigation of Honey Samples from Bee Farmers in Ekiti State, Southwest \\ Nigeria. Journal of Plant Sciences. Vol. 2, No. 5, 2014, pp. 246-249. doi: 10.11648/j.jps.20140205.26
}

\begin{abstract}
Fifteen honey samples obtained from different locations in Ekiti State, Southwest Nigeria were analyzed for some physico-chemical attributes including $\mathrm{pH}$, moisture contents, ash contents, total acidity, total solid, proline contents. The results showed a range of honey colours from amber to dark brown. The $\mathrm{pH}$ of the samples ranged from 3.73 to $4.60 \mathrm{while}$ the total solid ranged between $76.60 \%$ to $90.73 \%$, moisture content varied from $9.72 \%$ to $23.40 \%$, ash 0.004 to $0.440 \%$ and total acidity 21.5 to 33.6 meqkg $^{-1}$. Twelve samples passed proline tests while three failed proline test. Generally, the findings showed that the attributes of twelve of the commercial honeys agreed with the international standards which make them good for human consumption while others have higher values than normal level in certain parameters, thus suggesting some level of adulteration by farmers.
\end{abstract}

Keywords: Honey, Physico-Chemical Attributes, Adulteration, Ekiti State, Nigeria

\section{Introduction}

Honey is a semi liquid, yellow, sweet and flavoured food stuff, with a great biological and calorific value made by bees from nectar or sweet juice that can be found in different parts of the flowering plants. The composition and the flavor of honey depends on a huge number of variables, the most important of which is the type or types of plant that provided the source nectar, climatic condition during productions, processing and storage condition, beekeeping practices in removing and extracting honey $[1,2,3]$. Because of multiple importance of honey from food to medicine, it is of great interest to carry out complete analysis of honey and to formulate values ranges of various honey constituents and characteristics. Honeys industries have shown great interest in these constituents as they influence the storage quality, granulation, texture, flavour, nutritional and medicinal values of the honey. Honey is generally evaluated by a physicochemical analysis of its constituents. Knowing honey characteristics allows the packaging and storage of honey in appropriate conditions so as to preserve their qualities and savour [4]. In addition it provides information regarding the energetic and nutritional quality, as well as the possibility of falsifying honey. Indeed, according to [5], physico-chemical characteristics such as electrical conducting, $\mathrm{pH}$, ash content and specific rotation are widely used to differentiate botanical and geographical origins of honey and then complete pollen analysis.

Characterization of honey aids our understanding of its properties and medicinal applications [6]. Previous studies have been carried out on physical and chemical properties of Nigeria honeys from different locations. [7], established the elementary concentration (minerals) and functional groups present in some honey samples in the southeast and southwest of Nigeria. [8], elucidated the content of total titrable acidity, brix content, $\mathrm{pH}$, colour, moisture contents, ash contents and microbiological analysis of some Nigeria honey. [9], assessed the quality of Nigeria honey compared to manuka honey.

Ekiti State has great potential of beekeeping, however, reliable information on the bee plants, types of honey and nectar flow in this area is as yet highly limited and inadequate. To our knowledge there is no detailed study on the chemical or physical characterization of Ekiti honeys. Therefore, in the present investigation, we present the results of our preliminary studies of the physicochemical characteristics of Ekiti honey samples according to codex Alimentrius norms. 


\section{Materials and Methods}

\subsection{Collection of Samples}

Fifteen commercial honey samples were collected from different bee farmers in Ekiti State, Nigeria. The honey samples were kept in clean bottles and stored in a dark cupboard at room temperature for not more than three weeks. The samples were taken to the laboratory for investigation. The analyses were done at Sunshine Honey and Agro. Industries Limited, Alagbaka, Akure and Poultry Meat Research Laboratory, Department of Agricultural Extension and Rural Development, Obafemi Awolowo University, Ife, Osun State.

\subsection{Physico-Chemical Analyses}

Colour: The colour of the samples was determined by using the P-fund scale (mm). $2 \mathrm{ml}$ of the honey sample was taken in beaker, the instrument was calibrated and dipped into the sample while the readings was from the meter and compared [10].

Determination of $\mathrm{pH}$ : The $\mathrm{pH}$ was measured using a digital pH meter model H18519 (Hanna instrument).

Moisture content: The moisture was assessed by measuring $10.0 \mathrm{~g}$ of each sample and put in a flat dish and dried in the oven at $105^{\circ} \mathrm{C}$ for three hours, covered, cooled in desiccators and weighed. The sample was re-dried for one hour in the oven, cooled and reweighed. The process was repeated at one hour intervals until a constant weight was obtained [11].

Determination of ash content: About $2.50 \mathrm{~g}$ of each sample was put in a crucible and dried in an oven at $105^{\circ} \mathrm{C}$ for three hours to prevent loss by foaming. After cooling it was ashes in a muffle model furnace at $600^{\circ} \mathrm{C}$ overnight (for 6 hours). It was later cooled and weighed to a constant weight [11].

Free acidity: Ten grams of honey were weighed in a glass beaker and then $75 \mathrm{ml}$ of de-ionized water were added. This solution was titrated with $\mathrm{NaOH} 0.05$ mol. $\mathrm{L}^{-1}$ until reaching pH 8.5, and measured with a Horiba F 42 (Japan) pH-meter. Then $10 \mathrm{ml}$ of $\mathrm{NaOH} 0.05 \mathrm{~mol}^{-}$were added titrated again with $0.05 \mathrm{~mol} \mathrm{~L}^{-1} \mathrm{HCL}$ until reaching $\mathrm{pH} 8.30$. Total acidity was obtained by adding free lactonic acidities [12]. The results were expressed as meqkg ${ }^{-1}$ of acids.

Determination of total solids: The percentage total solid of each sample was determined using the following formula:

$$
\text { Total solids }(\%)=100-\text { Moisture content. }
$$

Determination of total titrable acidity: Twenty five mililitre of each samples (diluted) was titrated against $0.1 \mathrm{~N}$ $\mathrm{NaOH}$ using $\mathrm{ML}$ phenolphthalein as an indicator. The relative amount of lactic acid was determined using the following formulae:

$$
\text { Lactic acid }(\%)=\frac{\text { titre value } \times \text { Normality of } \mathrm{NaOH} \times 9}{\text { Volume of sample }}
$$

\begin{tabular}{|c|c|c|c|c|c|c|c|c|c|c|}
\hline Location & Taste & Odour & Colour & pH & Total Solid (\%) & $\begin{array}{l}\text { Volatile } \\
\text { matter }\end{array}$ & $\begin{array}{l}\text { Moisture } \\
\text { Content (\%) }\end{array}$ & $\begin{array}{l}\text { Ash Content } \\
(\%)\end{array}$ & $\begin{array}{l}\text { Free Acidity } \\
\text { (meqkg-1) }\end{array}$ & $\begin{array}{l}\text { Proline } \\
\text { content }\end{array}$ \\
\hline ARAMOKO & Good & Good & Dark brown & 3.89 & 85.42 & 0.429 & 14.58 & 0.090 & 28.0 & Passed \\
\hline OYE & Fair & Good & Golden & 3.98 & 90.73 & 0.160 & 9.27 & 0.243 & 33.6 & Passed \\
\hline ADO I & Excellent & Excellent & Golden & 4.50 & 80.20 & 0.276 & 19.80 & 0.063 & 22.4 & Passed \\
\hline OMUO & Excellent & Excellent & Golden & 3.85 & 87.64 & 1.109 & 12.36 & 0.020 & 22.4 & Passed \\
\hline IGEDE & Bitter & Fair & Golden yellow & 3.73 & 84.49 & 0.637 & 15.51 & 0.150 & 22.4 & Failed \\
\hline ESURE & Bitter & Fair & Golden yellow & 4.18 & 87.40 & 0.140 & 12.61 & 0.167 & 33.6 & Passed \\
\hline ADO II & Bitter & Fair & Golden & 3.90 & 85.39 & 0.560 & 14.61 & 0.004 & 33.6 & Failed \\
\hline IKOLE & Very Good & Very good & Golden brown & 3.94 & 84.49 & 1.037 & 14.16 & 0.080 & 33.6 & Passed \\
\hline AGBADO & Excellent & Excellent & Golden brown & 3.84 & 86.07 & 0.100 & 13.93 & 0.127 & 33.6 & Passed \\
\hline USI & Bitter & Fair & Amber & 3.77 & 86.24 & 0.887 & 13.76 & 0.177 & 22.4 & Failed \\
\hline OTUN & Very Good & Very good & Golden brown & 4.50 & 78.60 & 0.236 & 21.40 & 0.125 & 22.4 & Passed \\
\hline ARE & Good & Good & Golden & 3.92 & 87.39 & 0.120 & 12.66 & 0.150 & 22.4 & Passed \\
\hline ISE & Good & Fair & Golden brown & 4.60 & 76.60 & 0.520 & 23.40 & 0.221 & 28.0 & Passed \\
\hline
\end{tabular}

Table 1. Physico-Chemical Analysis of Honey Samples from Ekiti State

\section{Results and Discussion}

Results of organoleptic and physico-chemical characteristics of the fifteen honey samples from Ekiti State are reported in Table 1. The taste of the honey samples ranged from fair to bitter, good to very good to excellent. The odour of the honey samples ranged from fair to good to very good to excellent. The physical observation showed that the honey colour varied from amber to golden brown to dark brown. Honey taste, odour and colour are the physical properties that usually encountered by the consumers [3]. [13] and [14] reported honey colour ranged from colourless to dark colour. Honey samples from Adamawa have been reported by $[8,15]$ to have colour varied from yellow to dark yellow brown. Dark coloured honeys have been reported to contained more phenolic acid derivates but less flavonoids than light coloured honey [16]. Also dark coloured honey contained more minerals, mainly iron, copper and manganese which makes it good for medicinal uses [17, 18]. Variation in the honey taste, odour and colour was influenced by nectar source, nectar colouration, pollen colour, sugar reaction and the duration of storage. Light coloured honey is mild in flavor and a darker honey has a more pronounced flavor. 
Honey flavor is an important quality for its application in food industry and also a selection criterion for consumer's choice. Flavor and aroma judgments are personal and varied from one consumer to another hence these parameters are not enough to determine honey quality. $\mathrm{pH}$ values of the fifteen honey samples investigated ranged between 3.76 to 4.60 . All the honey samples investigated were acidic. These values were in conformity with the reports of some previous authors 3.47 to 4.24 were reported by [19] , and 2.90 to 4.26 by [9] for some honey samples in Nigeria. [20] reported that $\mathrm{pH}$ of honey samples should be between 3.2 and 4.50. Consequent on these values, the honey samples in this study were within the acidic range of $\mathrm{pH}$ and low enough to inhibit the growth of microbial organisms. The free acidity as recorded in this study ranged from 21.5 to $33.6 \mathrm{meq} / \mathrm{kg}$ (Table1). These results were in agreement with the previous works of [21] who reported the values of free acidity from different areas of Ibadan that ranged between 17.4 to $32.4 \mathrm{meg} / \mathrm{kg}$. The total acidity of all the honey samples analyzed were within the maximum value of $50 \mathrm{meq} / \mathrm{kg}$ allowed by national regulation [22]. The values reported in this study which are lower than $50 \mathrm{meq} / \mathrm{kg}$ suggest that the honey samples will not be fermented. The $\mathrm{pH}$ and the free acidity can influence honey stability and honey storage condition [23]. These parameters also provide useful information on the botanical origin of honey $[24,25]$. The moisture content of the honey sample as shown in Table 1 revealed a range between 9.27 to $23.40 \%$. Except honey samples from Otun $(21.40 \%$ Table 1$)$ and Ise (23.40\% Table1), other honey samples examined have moisture content within the standard limits. According to Codex Alimentarius [26] and European Union standard of honey samples [27], the maximum value of moisture content in honey is $21 \%$. United States of America Standards reported moisture of good quality to be between 18.0 and $20.0 \%$ [28]. One of the basic quality characteristics of honey is moisture content. Moisture content contribute to honey quality, its viscosity, its fermentation and savour. Low moisture content better aroma of honey and also form an important part of the system which protects honey from microbial attack [29]. The value obtained for ash content of the honey samples varied from 0.004 to $0.440 \%$ which is within the acceptable range. The results obtained is in agreement with the previous work of [30] who recorded ash content between the range of 0.05 to $0.60 \%$ for Ethiopia honeys. [31] reported $0.1 \%-1.0 \%$ for honey samples from Ethiopia. [22] proposed not more than $0.6 \%$ ash content for normal honey. The ash content of the honey samples indicates good physical property of honey. The result of the total solid varied from 76.60 to $90.73 \%$ which is in agreement with the report of [16]. The values falls within the prescription of Codex Alimentarium and European Union Standard reports. The solid is a measure of the combined content of the inorganic and organic substances. The reduction or absence shows that the honey sample has undergo further processing. It was assumed that the volatiles in honey originate from the plant species where the nectar had been gathered. Information obtained from a honey sample by analyzing its volatile composition may be useful for challenging classifications of the botanical origin [32] . In all the honey samples examined twelve honey samples passed proline test while 3 honey samples failed the test. Proline is the main amino acid in honey and originates predominantly from the bee. Authors such as [33], reported proline content to vary considerably between different honey samples. Proline concentration is used as an indicator of ripeness and detection of adulteration of honey [34].

\section{Conclusion}

In conclusion, $80 \%$ of the honey samples investigated were found to be within the acceptable range of international standards. With respect to flavor, color, $\mathrm{pH}$, moisture content, proline and ash content, Ekiti State honeys have good quality and this standard could easily be sustained through awareness and regular training of local bee farmers in honey harvesting and storage.

\section{References}

[1] White, J.W. 1978. Honey. Food Research Advances, 24, 287474.

[2] Nour, M. 1988. Some factors affecting quality of Egyptian Honey. Ph. D, Thesis In Economic Enthomology, Cairo University.

[3] Bogdanov, S., Kaspar, R., Livia, P.O. 2004. Physico-chemical methods for the characterization of Unifloral Honeys: A Review, Apidologie, 35: $\mathrm{Pp} \mathrm{S}_{4}-\mathrm{S}_{17}$.

[4] Clement, H., Bruneau, E., Barbancon, J.M., Bonnaaffe, P., Domerogo, R., Fert, G., Le Conte, Y., Ratia, J., Reeb, C., Veissiere, B. 2002. Le traite rustica de l'apiculture. Paris: Tralte Rustica, p. 528.

[5] Ouchemoulkh, S., Loualleche, N., Schweltzer, P. 2007. Physico-chemical characteristics and pollen spectrum of some Algerian honeys. Food control, 18: 52-58.

[6] Dunford, C.R., Copper, C.R., Molan, P., White, R. 2000. The use of Honey in wound management. Nursing Standard, 15:63-68.

[7] Adebiyi, F.M., Akpan, T., Obiajuwa, E.T., Olaniyi, H.B. 2004 Chemical and physical characterization of Nigeria honey. Pakistan. J. Nutr., 3:278-281.

[8] Lawal, R.A., Lawal, A.K., Adekalu, J.B. 2009. Physicochemical studies on Adulteration of Honey in Nigeria. Pakistan Journal of Biological Sciences, 12: 1080-1084.

[9] Agbagwa, O.E., Otokunefor, T.V., Frank-Peterside Nnenna. 2011. Quality assessment of Nigeria honey and Manuka honey. J. Microbiol. Biotech, Res., 1(3):20-31.

[10] Terrab, A., Recamales, A.F., Hernanz, D., Heredia, F.J. 2004. Characterization of Spanish thyme honey by their physicochemical characteristics and mineral contents. J. Food Chem. 4(88): 537-542. 
[11] A.O.A.C. 1990. Official methods of analysis. Sugars and sugar production in Horwtitz; W (Ed.), Official methods of analysis of A.OA.C International, Maryland, U.S.A, 2(44): 22-33.

[12] Naman, M., Faid, M., Adlorni, C. 2005. Microbiological and physicochemical properties of Moroccan honey. Int. J. Agric. Biol., 1560(5): 773-776..

[13] Krell, R. 1966. Value-Added Products from Beekeeping. FAO Agricultural Services Bulletin No. 124. Food and Agriculture Organization of the United Nations, Rome Italy, ISNI: 92-5103819-8.

[14] Anchling, F. 2007. L'Abeille de France et t'apiculteur, 942: 495-504.

[15] Igwe, E.C., Dandago, M. A., Binga, E. N. 2012. Assessment of quality attributes of natural honey from Adamawa State, North Eastern, Nigeria. African Journal of Food Science, 6 (18) pp. 449-455.

[16] Amiot, M. J., Aubert, S., Gonnet, M., Tacchini, M. 1989. Phelonic composition of honeys. Preliminary study on identification and group quantification, Apidologie, 20, 115125 .

[17] Gonzalez, A, Gomez, A., Garcia-Villano, R., Rivas, T., Ardaniv, R., Sanchez, J. 2000. Geographical discrimination of honey by using mineral composition and common chemical parameters. Journal of Science, Food and Agriculture, 80(1): 157-165.

[18] Buldini, P., Calvali, S., Mevoli, A., Sharma, J. 2001. Ion chromatographic and voltametric determination of heavy and transition metals in honey. Food Chemistry, 73:487-495.

[19] Jose, P., Maria, L. E., Xesus, F., Jesus, C., Antonio, I. 2009. Pollen spectrum and physico-chemical attributes of heather (Erica. sp) honeys of north Portugal, Journal of the Science of Food and Agriculture, 86(11): 1862-1870.

[20] Bogdanov, S., Bieri, K., Figar, M., Figueiredo, V., Iff, D., Kanzig, A., Stockl, H., Zurcher, K., Miel: 1995. definition et directives pour l'analyse et l'appreciation Centre Suisse de recherché Apicole: Station de recherché laitieres. Liebefeid., Berne.

[21] Adenekan, M. O., Amusa, N. A., Lawal, A. O., Okpeze, V. E. 2010. Physico-chemical and microbiological properties of honey samples obtained from Ibadan. Journal of Microbiology and Antimicrobials, 2(8), pp. 100-104.

[22] Codex Allimentarius Commission. 2001. Rapport de la 7e session du comite sur les sucres. Programme mixte FAO/OMS sur les norms alimentaries, p 31 .
[23] Nombre, I., Schweitzer, P., Boussim, J. I., Rasolodimby, J. M. 2010. Impacts of storage conditions on physicochemical characteristics of honey samples from Bukina Faso. African Journal of Food Science. 4(7): pp. 458-468.

[24] Persano Oddo, L., Piro, R. 2004. Main European unifloral honeys: descriptive sheets. Apidologie; 35 (Special issue), 3881 .

[25] Piazza, M. G., Persanno Oddo, L. 2004. Bibliography review of the main European unifloral honeys. Apidologie, 35 (Special issue), 94-111.

[26] Turlina, M. O., Fritz, R. 2005. .Int. J. Food Microbiol. 105: 297-307.

[27] Williams, E. T., Jeffrey, J., Barminas, J.T., Toma, I. 2009. Studies on the effects of the honey of two floral types (Zizphus spp and Acelia spp) on organism associated with burn wound infections. Afr. J. Pure Appl. Chem., 3: 098-101.

[28] USDA. 1970. United Standards for Grades of extracted honey, http:

//www.ams.usda.gov/AMSV/.o/yetfile2dDocName=STELDE V301 1895. Retrieved//May 2010.

[29] Tysset, C., Rousseau, M., Duran, C. 1980. Microbism and wholesomeness of commercial honey. Apiacta, 15: 51-60..

[30] Kinati, C., Tolemariam, T., Debele, K. 2011. Quality evaluation of honey produced in Gomma Woreda of South Western. Ethiopia Livestock Research for Rural Development, Volume 23, Article \#190.

[31] Nuru, A. 1999. Quality State and Grading of Ethiopian Honey. In Proceedings of First National Conference of the Ethiopian Beekeepers Association. 74-82, Addis Ababa, Ethiopia.

[32] Ruoff, K. Solid-Phase microextraction of honey volatiles. A method for the determination of the botanical origin of honey. University of Helsinki, Dept. of Applied Biology; Apiculture, 2003.

[33] Bogdanov, S., Lullman, C., Martin, P., Ohe Vonder, W., Russman, H., Vorwohl, G., Persano Oddo, L., Sabatini, A. G., Marcazzan, A.G., Piro, R., Flamini, C., Morlot, M., Lehritier, J., Borneck, R., Marioleas, P., Tsiguori, A., Kerkuliet, J., Ortiz, A., Ivanov, T., Darcy, B., Mossel, B., Vit, P. 1999. Honey quality and international regulatory standards: review by the International Honey Commission. Bee Wld, 80: 61-69.

[34] Von de Ohe, W., Dustmann, J. H., Van de Ohe, K. 1991. Prolin als Krlterium der Re; fe des Honigs Dtsch. Lebensm. Rundschau, 87: 383-386. 